OPEN ACCESS

Edited by:

Herve Boutin,

University of Manchester,

United Kingdom

Reviewed by:

Gian Marco Leggio,

Università degli Studi di Catania, Italy

Caroline E. Bass,

University at Buffalo, United States

*Correspondence:

Karolina Pytka

karolina.pytka@uj.edu.pl

Specialty section:

This article was submitted to

Experimental Pharmacology and Drug

Discovery,

a section of the journal

Frontiers in Pharmacology

Received: 18 May 2018 Accepted: 21 September 2018 Published: 16 October 2018

Citation:

Pytka K, Głuch-Lutwin M, Żmudzka $E$, Sałaciak $K$, Siwek $A$, Niemczyk K, Walczak M, Smolik M,

Olczyk A, Gałuszka A, Śmieja J,

Filipek B, Sapa J, Kołaczkowski M,

Pańczyk K, Waszkielewicz A and Marona H (2018) HBK-17, a 5-HT $1 A$ Receptor Ligand With Anxiolytic-Like Activity, Preferentially Activates B-Arrestin Signaling.

Front. Pharmacol. 9:1146.

doi: 10.3389/fphar.2018.01146

\section{HBK-17, a 5-HT 1 A Receptor Ligand With Anxiolytic-Like Activity, Preferentially Activates B-Arrestin Signaling}

Karolina Pytka'*, Monika Głuch-Lutwin², Elżbieta Żmudzka', Kinga Sałaciak', Agata Siwek ${ }^{2}$, Katarzyna Niemczyk ${ }^{1}$, Maria Walczak ${ }^{3}$, Magdalena Smolik', Adrian Olczyk ${ }^{4}$, Adam Gałuszka ${ }^{4}$, Jarosław Śmieja ${ }^{5}$, Barbara Filipek ${ }^{1}$, Jacek Sapa ${ }^{1}$, Marcin Kołaczkowski ${ }^{6}$, Katarzyna Pańczyk ${ }^{7}$, Anna Waszkielewicz ${ }^{7}$ and Henryk Marona ${ }^{7}$

${ }^{1}$ Department of Pharmacodynamics, Faculty of Pharmacy, Jagiellonian University Medical College, Krakow, Poland, ${ }^{2}$ Department of Pharmacobiology, Faculty of Pharmacy, Jagiellonian University Medical College, Krakow, Poland, ${ }^{3}$ Chair and Department of Toxicology, Faculty of Pharmacy, Jagiellonian University Medical College, Krakow, Poland, ${ }^{4}$ Control and Robotics Group, Faculty of Automatic Control, Electronics and Computer Science, Institute of Automatic Control, Silesian University of Technology, Gliwice, Poland, ${ }^{5}$ Systems Engineering Group, Faculty of Automatic Control, Electronics and Informatics, Institute of Automatic Control, Silesian University of Technology, Gliwice, Poland, ${ }^{6}$ Department of Medicinal Chemistry, Faculty of Pharmacy, Jagiellonian University Medical College, Krakow, Poland, ${ }^{7}$ Department of Bioorganic Chemistry, Chair of Organic Chemistry, Faculty of Pharmacy, Jagiellonian University Medical College, Krakow, Poland

Numerous studies have proven that both stimulation and blockade of $5-\mathrm{HT}_{1 \mathrm{~A}}$ and the blockade of $5-\mathrm{HT}_{7}$ receptors might cause the anxiolytic-like effects. Biased agonists selectively activate specific signaling pathways. Therefore, they might offer novel treatment strategies. In this study, we investigated the anxiolytic-like activity, as well as the possible mechanism of action of 1-[(2,5-dimethylphenoxy)propyl]-4(2-methoxyphenyl)piperazine hydrochloride (HBK-17). In our previous experiments, HBK-17 showed high affinity for $5-\mathrm{HT}_{1 \mathrm{~A}}$ and $5-\mathrm{HT}_{7}$ receptors and antidepressantlike properties. We performed the four plate test and the elevated plus maze test to determine anxiolytic-like activity. Toward a better understanding of the pharmacological properties of $\mathrm{HBK}-17$ we used various functional assays to determine its intrinsic activity at $5-\mathrm{HT}_{1 \mathrm{~A}}, 5-\mathrm{HT}_{2 \mathrm{~A}}, 5-\mathrm{HT}_{7}$, and $\mathrm{D}_{2}$ receptors and UHPLC-MS/MS method to evaluate its pharmacokinetic profile. We observed the anxiolytic-like activity of HBK-17 in both behavioral tests and the effect was reversed by the pretreatment with WAY-100635, which proves that $5-\mathrm{HT}_{1 \mathrm{~A}}$ receptor activation was essential for the anxiolytic-like effect. Moreover, the compound moderately antagonized $\mathrm{D}_{2}$, weakly $5-\mathrm{HT}_{7}$ and very weakly $5-\mathrm{HT}_{2 \mathrm{~A}}$ receptors. We demonstrated that $\mathrm{HBK}-17$ preferentially activated $\mathrm{B}$-arrestin signaling after binding to the $5-\mathrm{HT}_{1 \mathrm{~A}}$ receptor. $\mathrm{HBK}-17$ was rapidly absorbed after intraperitoneal administration and had a half-life of about 150 min. HBK-17 slightly penetrated the peripheral compartment and showed bioavailability of approximately $45 \%$. The unique pharmacological profile of HBK-17 encourages further experiments to understand its mechanism of action fully.

Keywords: $5-\mathrm{HT}_{1 \mathrm{~A}}$ receptor, anxiolytic-like, mouse models, pharmacokinetics, $\mathrm{B}$-arrestin signaling 


\section{INTRODUCTION}

Brain serotonin participates in numerous physiological and pathological processes. It regulates mood, sleep, or cognitive function and modulates fear and anxiety processes. Serotonin exerts its effects interacting with at least 14 serotonin receptor subtypes. Among all of them, the $5-\mathrm{HT}_{1 \mathrm{~A}}$ receptor plays the most important role in the etiology of anxiety (reviewed by Akimova et al., 2009). The $5-\mathrm{HT}_{1 \mathrm{~A}}$ receptors are expressed both presynaptically and postsynaptically. The activation of presynaptic $5-\mathrm{HT}_{1 \mathrm{~A}}$ autoreceptors, present on serotonergic neurons in the raphe nuclei, reduces serotonergic neurons firing and decreases serotonin levels. On the other hand, the stimulation of postsynaptic $5-\mathrm{HT}_{1 \mathrm{~A}}$ receptors, located mainly on glutamatergic and GABAergic pyramidal neurons, modulates serotonergic sensitivity and participates in emotional and cognitive processes (for review see Garcia-Garcia et al., 2014).

Garcia-Garcia et al. (2014) in their review suggested that inhibiting serotonergic neuron firing and decreasing serotonin release, as well as reducing serotonergic signaling at postsynaptic target receptors might result in anxiolytic-like effects. Studies confirmed this theory, as stimulating $5-\mathrm{HT}_{1 \mathrm{~A}}$ receptors in the dorsal raphe nucleus caused an anxiolytic-like effect (Cervo et al., 2000), whereas activating the heteroreceptors in the medial septum and dorsal hippocampus was anxiogenic (File et al., 1996; De Almeida et al., 1998). Collinson and Dawson (1997) presented the anxiolytic-like effect of $5-\mathrm{HT}_{1 \mathrm{~A}}$ receptor agonist, 8-OH-DPAT, which was reversed by $5-\mathrm{HT}_{1 \mathrm{~A}}$ receptor antagonist (WAY-100635). Moreover, 5- $\mathrm{HT}_{1 \mathrm{~A}}$ knockout mice, lacking $5-\mathrm{HT}_{1 \mathrm{~A}}$ auto- and heteroreceptors, displayed a heightened anxiety-like phenotype in several tests in rodents (Heisler et al., 1998; Parks et al., 1998; Ramboz et al., 1998) and resistance to benzodiazepines (Sibille et al., 2000). Overall, the above findings demonstrate the involvement of $5-\mathrm{HT}_{1 \mathrm{~A}}$ receptors in anxiogenic processes.

The blockade of $5-\mathrm{HT}_{7}$ receptors might also be beneficial in anxiety. Yau et al. (2001) showed an increase in $5-\mathrm{HT}_{7}$ receptor mRNA expression after acute, but not chronic, stress in the rat hippocampus, which suggested the role of the $5-\mathrm{HT}_{7}$ receptor in stress regulation. Wesołowska et al. (2006b) demonstrated the anxiolytic-like activity of a selective $5-\mathrm{HT}_{7}$ receptor antagonist, SB-269970, in rodent models of anxiety. Similarly, intrahippocampal administration of the compound induced an antianxiety-like effect in the Vogel conflict test in rats (Wesołowska et al., 2006a). Thus, some studies suggest that 5-HT7 receptor antagonists might decrease anxiety symptoms.

Functional selectivity (also called biased signaling) is an ability of a ligand to direct a $G$ protein-coupled receptor toward a conformation that activates specific signal transduction pathway. Upon stimulation, the $5-\mathrm{HT}_{1 \mathrm{~A}}$ receptor can activate many signaling pathways, including adenylate cyclase inhibition, extracellular signal-regulated protein kinase (ERK) phosphorylation, G protein-coupled inwardly rectifying potassium channel activation, voltage-gated calcium channel inhibition, or the recruitment of B-arrestin (Chilmonczyk et al., 2015; Stroth et al., 2015). Newman-Tancredi et al. (2009) presented compounds highly selective for a $5-\mathrm{HT}_{1 \mathrm{~A}}$ receptor with biased agonist profiles, i.e., F15599 or F13714. F15599 showed a marked potency for ERK1/2 phosphorylation, which might underlie its potent antidepressant-like activity in rats. On the other hand, F13714, which presented lower potency for ERK1/2 phosphorylation (Newman-Tancredi, 2011), showed an exceptionally potent antidyskinetic activity in rats (Iderberg et al., 2015). This demonstrates that biased agonists at the $5-\mathrm{HT}_{1 \mathrm{~A}}$ receptor might present different pharmacological activity. Although it is not yet clear to what extent functional selectivity can be exploited for therapeutic advantage, some clinically used drugs, e.g., carvedilol (ß-blocker) show this effect (Patel et al., 2010; Kenakin, 2011). Moreover, scientists suggest that functional selectivity can explain the unique features of the antipsychotic drug - aripiprazole (Mailman and Murthy, 2010). Since biased agonists preferentially activate one pathway over others, they might offer novel treatment strategies, i.e., show pharmacological activity without inducing unwanted effects. Thus, compounds with functional selectivity might show interesting pharmacological properties in vivo and therefore are worth investigating.

We previously demonstrated antidepressant-like activity of 1[(2,5-dimethylphenoxy)propyl]-4-(2-methoxyphenyl)piperazine hydrochloride (HBK-17, Figure 1) in rodents (Waszkielewicz et al., 2015; Kubacka et al., 2016; Pytka et al., 2016a). The compound moderately antagonized $5-\mathrm{HT}_{1 \mathrm{~A}}$ receptors expressed in $\mathrm{CHO}-\mathrm{K} 1$ cells in $\mathrm{Ca}^{2+}$ mobilization assay and showed the affinity for $5-\mathrm{HT}_{7}$ receptors (Waszkielewicz et al., 2015; Kubacka et al., 2016; Pytka et al., 2016a). Since 5-HT $1 \mathrm{~A}$ and 5- $\mathrm{HT}_{7}$ receptors play a role in anxiety, we hypothesized that HBK-17 might influence anxiety-like behaviors in rodents. Therefore, our study aimed to investigate anxiolytic-like properties in mice, as well as the possible mechanism of action of HBK-17 using in vitro and in vivo experiments. As knowledge of pharmacokinetics and brain distribution of novel central-acting compounds is essential for the proper analysis of their in vivo effects, we also evaluated the compound's pharmacokinetic profile.

\section{MATERIALS AND METHODS}

\section{Animals}

We used adult male Albino-Swiss mice (CD-1) weighing 18-21 g in all experiments. The animals were kept in groups of 15 mice in cages at room temperature of $22 \pm 2{ }^{\circ} \mathrm{C}$ under light/dark $(12: 12)$ cycle and they had free access to food (standard laboratory

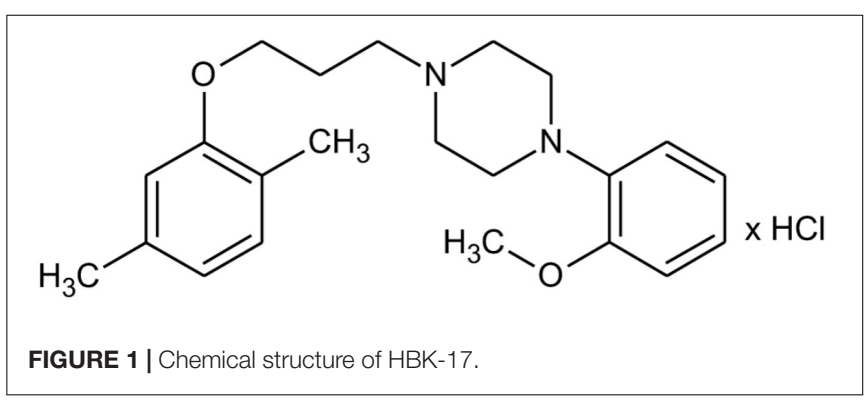


pellets) and water before experiments. Humidity and ambient temperature of the room were kept constant throughout all tests, which were conducted between 9 a.m. and 4 p.m. The animals were used only once in each test. All injections were given in a volume of $10 \mathrm{ml} / \mathrm{kg}$. Behavioral experiments were carried out by a trained observer blind to the treatments. All experimental procedures were approved by the I Local Ethics Committee for Experiments on Animals of the Jagiellonian University in Krakow (approval number 51/2015), Poland and performed under the guidelines provided by the European Union Directive of 22 September 2010 (2010/63/EU) and Polish legislation concerning animal experimentation.

\section{Drugs}

The tested compound 1-[(2,5-dimethylphenoxy)propyl]-4(2-methoxyphenyl)piperazine hydrochloride (HBK-17) was synthesized in the Department of Bioorganic Chemistry, Chair of Organic Chemistry, Jagiellonian University Medical College (Figure 1; Waszkielewicz et al., 2015). HBK-17 was dissolved in saline and administered intraperitoneally (i.p.) $30 \mathrm{~min}$ before behavioral experiments. p-Chlorophenylalanine (pCPA, Sigma, Germany) and $\alpha$-methyl-p-tyrosine (AMPT, Sigma, Germany) were suspended in 1\% Tween and administered i.p. WAY-100635 (Sigma, Germany) was injected subcutaneously (s.c.) $15 \mathrm{~min}$ before the studied compound.

\section{Radioligand Binding Assays}

Binding experiments were performed using membranes from CHO-K1 cells stably transfected with the human $\mathrm{D}_{2}$ receptor and rat cerebral cortex ( $\alpha_{2}$-adrenergic and $\mathrm{GABA}_{\mathrm{A}}$ receptors). $\left[{ }^{3} \mathrm{H}\right]$-Methylspiperon (final concentration $0.4 \mathrm{nM} ; \mathrm{D}_{2}$ receptor), $\left[{ }^{3} \mathrm{H}\right]$-clonidine (final concentration $0.2 \mathrm{nM} ; \alpha_{2}$-adrenergic receptor) and $\left[{ }^{3} \mathrm{H}\right]$-muscimol (final concentration $1 \mathrm{nM}$; GABA receptor) were used. The final incubation mixture (total volume $250 \mu \mathrm{l})$ consisted of a $50 \mu \mathrm{l}$ solution of the test compound, $50 \mu \mathrm{l}$ of radioligand and $150 \mu \mathrm{l}$ of diluted membranes or the tissue suspension. The incubation was terminated by rapid filtration over glass fiber filters GF/B (PerkinElmer, United States) using 96-well FilterMate Harvester (PerkinElmer, United States). Five rapid washes were performed with ice-cold $50 \mathrm{mM}$ Tris-HCl buffer ( $\mathrm{pH} 7.4$ or 7.6). The radioactivity was measured in MicroBeta TriLux 1450 - liquid scintillation counter (PerkinElmer, United States). Radioligand binding data were analyzed using iterative curve fitting routines GraphPad Prism 5.0 (GraphPad Software). Ki values were calculated from the Cheng and Prusoff (1973) equation. The concentrations of analyzed compounds ranged from $10^{-10}$ to $10^{-5} \mathrm{M}$. For measuring unspecific binding, clonidine - $10 \mu \mathrm{M}$ (in case of $\left[{ }^{3} \mathrm{H}\right]$-clonidine) and haloperidol - $1 \mu \mathrm{M}$ (in case of $\left[{ }^{3} \mathrm{H}\right]$-methylspiperon) and diazepam - $100 \mu \mathrm{M}$ (in case of $\left[{ }^{3} \mathrm{H}\right]$-muscimol) were applied. At least two independent experiments were performed for each assay.

\section{Functional Assays}

Serial dilutions were prepared in 96-well microplate in appropriate dilution buffer (HBSS or medium) with $0.1 \%$ BSA added, and 8-10 concentrations were tested in duplicates.
At least two independent experiments were performed for each type of method. Assays were done according to manufacturer's protocols.

The level of cAMP (TRF0263, PerkinElmer assay kit) was monitored using $\mathrm{CHO}-\mathrm{K} 1$ cells with expression of the human serotonin $5-\mathrm{HT}_{1 \mathrm{~A}}$ receptor. The cells were resuspended in stimulation buffer at $2 \times 10^{5}$ cells $/ \mathrm{ml}$. The same volume $(10 \mu \mathrm{l})$ of cells was added to tested compounds with $10 \mu \mathrm{M}$ forskolin. The antagonist response was performed using as a reference agonist, serotonin, in $\mathrm{EC}_{80}(120 \mathrm{nM})$. Samples were loaded onto a white opaque half area 96-well microplate, incubated for $40 \mathrm{~min}$ at room temperature. The $10 \mu \mathrm{l}$ of reagents were added, mixed, and incubated for $1 \mathrm{~h}$. The homogeneous TR-FRET signal was read on an EnVision Microplate Reader (PerkinElmer, United States).

The CHO-5HT1A receptor cells were tested for phosphorylated-ERK (p-ERK) using the SureFire ERKPhosphorylation AlphaLISA Assay Kit according to the manufacturer's instruction (ALSU-PERK-A10K, PerkinElmer). At the experiment, cells were plated at 50,000 cells/well of 96-well plate and grown $7 \mathrm{~h}$ in an incubator $\left(5 \% \mathrm{CO}_{2}, 37^{\circ} \mathrm{C}\right)$. The serial dilutions of compounds were added and incubated for $15 \mathrm{~min}$ at $37^{\circ} \mathrm{C}$. The antagonist response was performed using serotonin as a reference agonist at the concentration equal to $\mathrm{EC}_{80}(45 \mathrm{nM})$. The "lysis buffer" (70 $\mu \mathrm{l})$ was added and the plate gently agitated on a plate shaker $(10 \mathrm{~min})$. The $10 \mu \mathrm{l}$ of samples were transferred to assay plates (384-OptiPlate, PerkinElmer) in duplicates and $10 \mu \mathrm{l}$ of the reaction mix was added. The plates were incubated for $2 \mathrm{~h}$ at $22^{\circ} \mathrm{C}$ and measured with an EnVision a multifunction plate reader (PerkinElmer Life Science).

The HTR1A-bla U2OS receptor cells were tested using the Tango LiveBLAzer $\beta$-arrestin assay kit according to the manufacturer's instruction (K1095, Life Technologies). At the experiment, cells were plated at 10,000 cells/well of 384-well black, clear bottom plate and grown $12 \mathrm{~h}$ in an incubator $\left(5 \% \mathrm{CO}_{2}, 37^{\circ} \mathrm{C}\right)$. The serial dilutions of compounds were added and incubated for $5 \mathrm{~h}\left(5 \% \mathrm{CO}_{2}, 37^{\circ}\right)$. The antagonist response was performed using serotonin as a reference agonist at the concentration equal to $\mathrm{EC}_{80}(300 \mathrm{nM})$. After this time, $8 \mu \mathrm{l}$ of the reaction mix was added. The plates were incubated for $2 \mathrm{~h}$ at $22^{\circ} \mathrm{C}$ and measured with a FLUOstar OPTIMA a multifunction plate reader (PerkinElmer Life Science).

\section{Behavioral Experiments}

\section{Four Plate Test}

The four plate test was performed on mice according to the method previously described (Aron et al., 1971; Bourin et al., 2005; Pytka et al., 2016b). Mice were placed individually in the four plate apparatus connected to the power source. After a $15 \mathrm{~s}$ of habituation period, each mouse crossing from one plate to another (two limbs on one plate, two on another) was punished by an electric shock $(0.8 \mathrm{~mA}, 0.5 \mathrm{~s})$. If the mouse continued running, it received no new shock for the following $3 \mathrm{~s}$. The number of punished crossings was calculated during the $60 \mathrm{~s}$ of the test. HBK-17 was dissolved in saline and administered i.p. $30 \mathrm{~min}$ before the test. 


\section{Elevated Plus Maze}

The elevated plus maze was performed according to the method previously described (Lister, 1987; Pytka et al., 2017). The elevated plus maze for mice consisted of two opposing open $(30 \mathrm{~cm} \times 5 \mathrm{~cm})$, and two enclosed arms $(30 \mathrm{~cm} \times 5 \mathrm{~cm} \times 25 \mathrm{~cm})$ connected by a central platform forming the shape of a plus sign. The open and closed arms were connected with a central field $(5 \mathrm{~cm} \times 5 \mathrm{~cm})$. Each mouse was individually placed at the central field of the apparatus with the head turned toward one of the closed arms. Animal behavior was observed for $5 \mathrm{~min}$. The device was disinfected with $70 \%$ ethanol after each mouse. The number of entries to open and closed arms and time spent in the open and closed arms were measured. The experiments were recorded and scored using aLab.io software by a trained observer blind to the treatments. HBK-17 was dissolved in saline and administered i.p. $30 \mathrm{~min}$ before the test.

\section{Spontaneous Locomotor Activity}

Spontaneous locomotor activity was performed as previously described (Pytka et al., 2015a). Photoresistor actometers (Ugo Basile, Italy) connected to a counter for the recording of lightbeam interruptions were used to investigate the effect of the compound on locomotor activity in mice. Locomotor activity was counted as the number of the light-beam crossing. It was recorded individually for each animal. After administration of the tested compound, each mouse was placed separately in a cage for $30 \mathrm{~min}$ habituation period. After that time, the parameter was measured for $1 \mathrm{~min}$ and $5 \mathrm{~min}$ (i.e., time equal to the observation period in four plate test and elevated plus maze test, respectively). The cages were sanitized with $70 \%$ ethanol after each mouse. HBK-17 was dissolved in saline and administered i.p. $30 \mathrm{~min}$ before the test.

\section{Hot Plate Test}

The hot plate test was performed as described by Sałat et al. (2015). The hot plate apparatus (Hot/Cold Plate, Bioseb, France) consisted of an electrically heated surface and was equipped with a temperature controller that keeps the temperature constant at $55-56^{\circ} \mathrm{C}$. One day before the experiment, the animals were tested for their pain sensitivity threshold (baseline latency). We chose only mice that showed baseline latencies $\leq 30 \mathrm{~s}$. The latency time to pain reaction (licking hind paws or jumping) was measured as the indicative of nociception (cutoff time - $60 \mathrm{~s}$ ). Animals that did not respond within $60 \mathrm{~s}$ were removed from the hot plate apparatus and assigned a score of $60 \mathrm{~s}$. HBK-17 was dissolved in saline and administered i.p. $30 \mathrm{~min}$ before the test.

\section{Serotonin Synthesis Blockade}

To assess the involvement of the serotonergic system in the anxiolytic-like effect of HBK-17, we used pCPA (tryptophan hydroxylase inhibitor) as previously described (Pytka et al., 2015b). We injected mice with pCPA at a dose of $200 \mathrm{mg} / \mathrm{kg}$ for three consecutive days. $24 \mathrm{~h}$ after the last pCPA administration, we injected mice with saline (i.p.) or HBK-17 (5 mg/kg, i.p.). We performed the four plate test $30 \mathrm{~min}$ after the administration.

\section{Noradrenaline and Dopamine Synthesis Blockade}

To investigate the involvement of the noradrenergic and dopaminergic systems in the anxiolytic-like effect of HBK-17, we pretreated mice i.p. with a catecholamine synthesis inhibitor, AMPT (tyrosine hydroxylase inhibitor) at the dose of $100 \mathrm{mg} / \mathrm{kg}$. Control group received vehicle (1\% Tween). Four hours after AMPT or $1 \%$ Tween injection, mice were pretreated with saline (i.p.) or HBK-17 (5 mg/kg, i.p.). We performed the four plate test 30 min after the compound administration.

\section{Pharmacokinetic Experiments Instrumentation and Bioanalysis}

The LC/ESI-MS/MS experiments were performed on TSQ Quantum Triple Quadrupole Mass Spectrometer (Thermo Scientific, United States) equipped with an electrospray ionization interface. This instrument was coupled to Dionex 3000 (Dionex, United States) ULPC system. Data acquisition and processing were accomplished using Xcalibur data collection and integration software. The mobile phase consisted of a mixture of acetonitrile with an addition of $0.1 \%$ formic acid (Solvent A) and water with an addition of $0.1 \%$ formic acid (Solvent B) was set at a flow rate of $0.3 \mathrm{ml} / \mathrm{min}$ in gradient elution. Sample preparations were carried out by precipitation procedure using acetonitrile after the addition of the internal standard [IS, 2-(4methyl-1-piperazinyl)-4-phenylquinazoline]. The dried residue was reconstituted in the mobile phase and injected onto an Acclaim Polar Advantage Column $(1.8 \mu \mathrm{m}, 100 \mathrm{~mm} \times 2.1 \mathrm{~mm}$, Dionex).

The method was validated according to validation procedures, parameters and acceptance criteria based on USP XXIII guidelines and FDA criterion 20/15.

\section{Pharmacokinetic Study in Mice}

All data in pharmacokinetic experiments were processed with the pharmacokinetics software Phoenix WinNonlin (Certara Company, United States). The non-compartmental pharmacokinetic parameters of $\mathrm{t}_{1 / 2}, \mathrm{MRT}, \mathrm{AUC}, \mathrm{Cl}$, and $\mathrm{V}_{\mathrm{d}}$ were calculated based on moment methods. First order elimination rate constant $\left(\lambda_{\mathrm{z}}\right)$ was calculated by linear regression of time vs. $\log$ concentration according to Eq. 1.

$$
\lambda_{\mathrm{z}}=-2.303 a
$$

where $\mathrm{a}$ is a slope of a line.

The terminal half-life $\left(t_{1 / 2}\right)$ was calculated as:

$$
t_{1 / 2}=\frac{0.693}{\lambda_{z}}
$$

The area under curve the mean plasma and tissue concentration vs. time curve extrapolated to infinity $\left(\mathrm{AUC}_{0 \rightarrow \infty}\right)$ was estimated using the log-linear trapezoidal rule (Eq. 3), here $C_{n}$ is the concentration of last sampling.

$$
A U C_{0 \rightarrow \infty}=\sum_{\mathrm{i}=1}^{n}\left(\frac{C_{\mathrm{i}}+C_{\mathrm{i}+1}}{2}\right) \cdot\left(t_{\mathrm{i}+1}-t_{\mathrm{i}}\right)+\frac{C_{\mathrm{n}}}{\lambda_{\mathrm{z}}}
$$

Area under the first-moment curve $\left(\mathrm{AUMC}_{0 \rightarrow \infty}\right)$ was estimated by calculation of total area under the first-moment curve and 
extrapolated area using the Eq. 4 , where $t_{n}$ is the time of last sampling.

$$
\begin{aligned}
A U M C_{0 \rightarrow \infty}= & \sum_{\mathrm{i}=1}^{n}\left(\frac{t_{\mathrm{i}} \cdot C_{\mathrm{i}}+t_{\mathrm{i}+1} \cdot C_{\mathrm{i}+1}}{2}\right) \cdot\left(t_{\mathrm{i}+1}-t_{\mathrm{i}}\right) \\
& +\frac{t_{\mathrm{n}} \cdot C_{\mathrm{n}}}{\lambda_{\mathrm{z}}}+\frac{C_{\mathrm{n}}}{\lambda_{\mathrm{z}}^{2}}
\end{aligned}
$$

Mean residence time (MRT) was calculated as:

$$
M R T=\frac{A U M C_{0 \rightarrow \infty}}{A U C_{0 \rightarrow \infty}}
$$

Systemic clearance $(\mathrm{Cl})$ was calculated as:

$$
C l=\frac{D_{\mathrm{iv}}}{A U M C_{0 \rightarrow \infty}}
$$

Volume of distribution $\left(\mathrm{V}_{\mathrm{d}}\right)$ was calculated as:

$$
V_{\mathrm{d}}=\frac{D_{\mathrm{iv}}}{C_{0}}
$$

were $D_{i v}$ is an intravenous dose and $C_{0}$ is an initial concentration.

The bioavailability (F) of the studied compound after an intraperitoneal administration compared to the intravenous route was calculated as:

$$
F=\frac{A U C_{\text {i.p. }} \cdot D_{\text {i.v. }}}{A U C_{\text {i.v. }} \cdot D_{\text {i.p. }}} \cdot 100 \%
$$

\section{Data Analysis}

Results are presented as means \pm SEM. They were estimated using one or two-way analysis of variance (ANOVA), followed by Newman-Keuls or Bonferroni post hoc, respectively. Differences between groups were considered as significant if $p<0.05$.

\section{RESULTS}

\section{HBK-17 Moderately Antagonized $D_{2}$ and Weakly 5-HT 7 Receptors}

The radioligand binding experiments revealed that compared with the reference compound, haloperidol, HBK-17 moderately bound to $\mathrm{D}_{2}$ receptors. $\mathrm{HBK}-17$ did not show the affinity for $\alpha_{2}$ adrenoceptors or $\mathrm{GABA}_{\mathrm{A}}$ receptors, while the reference drugs clonidine and diazepam strongly bound to these receptors, respectively (Table $\mathbf{1}$ ).

Since HBK-17 showed a moderate affinity for $D_{2}$, $5-\mathrm{HT}_{2 \mathrm{~A}}$, and $5-\mathrm{HT}_{7}$ receptors, we investigated its intrinsic activity toward these receptors. The results of the functional assays showed that HBK-17 had no agonistic properties, but it blocked dopamine $\mathrm{D}_{2}$ receptor. Its value of the equilibrium dissociation constant for a competitive antagonist $\left(\mathrm{K}_{\mathrm{b}}\right)$ was 7.4 -fold lower than the $\mathrm{K}_{\mathrm{b}}$ value of the reference antagonist - chlorpromazine (Table 2). Similarly, HBK-17 did not show any agonistic properties at serotonin $5-\mathrm{HT}_{7}$ receptor but blocked the
TABLE 1 | The affinity of HBK-17 for adrenergic $\alpha_{2}$, dopaminergic $D_{2}$, and GABAergic $\mathrm{GABA}_{A}$ receptors.

\begin{tabular}{lccc}
\hline Compound & $\begin{array}{c}\alpha_{\mathbf{2}} \text { receptors } \\
\mathbf{K}_{\mathbf{i}} \pm \text { SEM }[\mathbf{n M}]\end{array}$ & $\begin{array}{c}\mathbf{D}_{\mathbf{2}} \text { receptors } \\
\mathbf{K}_{\mathbf{i}} \pm \text { SEM }[\mathbf{n M}]\end{array}$ & $\begin{array}{c}\mathbf{G A B A}_{\mathbf{A}} \text { receptors } \\
\mathbf{K}_{\mathbf{i}} \pm \mathbf{S E M}[\mathbf{n M}]\end{array}$ \\
\hline HBK-17 & $17800 \pm 1.5$ & $51.4 \pm 0.7$ & $>10000$ \\
Clonidine & $2.5 \pm 0.1$ & - & - \\
Haloperidol & - & $1.1 \pm 0.1$ & - \\
Diazepam & - & - & $5.6 \pm 0.7$
\end{tabular}

Inhibition constants $\left(K_{i}\right)$ were calculated according to the equation of Cheng and Prusoff (1973).

receptor with $\mathrm{K}_{\mathrm{b}}$ value 78 -fold lower than the reference antagonist, SB269970 (Table 2). As demonstrated in Table 2 HBK-17 showed no agonistic properties and negligible antagonistic effect at serotonin $5-\mathrm{HT}_{2 \mathrm{~A}}$ receptor. Compared with the reference compound, $\alpha$-methylserotonin, HBK-17 blocked 5- $\mathrm{HT}_{2 \mathrm{~A}}$ receptor 1228.1-fold weaker (Table 2).

\section{HBK-17 Preferentially Activated B-Arrestin Recruitment After Binding to 5- $\mathrm{HT}_{1 \mathrm{~A}}$ Receptor}

A single receptor can activate numerous signaling pathways and influence cell function oppositely. Biased agonists stabilize the receptor's conformation preferentially, and consequently activate a selected signaling pathway. In our study we used cell cultures as they provide a valuable complement to in vivo experiments, allowing more controlled manipulation of the cellular functions and processes.

Although $5-\mathrm{HT}_{1 \mathrm{~A}}$ receptor couples to the broad panel of second messengers, the primary coupling linkage is to the inhibition of adenylate cyclase (Chilmonczyk et al., 2015). Therefore, first, we evaluated the influence of HBK-17 on cAMP production using $\mathrm{CHO}-\mathrm{K} 1$ cells with expression of the human serotonin $5-\mathrm{HT}_{1 \mathrm{~A}}$ receptor. Contrary to the reference compound, serotonin, HBK-17 did not inhibit cAMP formation. However, the studied compound showed antagonistic properties in this assay. HBK-17 demonstrated 6.1-fold lower $\mathrm{K}_{\mathrm{b}}$ value compared with the reference compound, WAY-100135 (Table 3).

To prevent over-stimulation $G$ protein-coupled receptors recruit cytosolic proteins - arrestins - which promote signaling termination. Thus, we determined the influence of HBK-17 on $\beta$-arrestin recruitment using HTR1A-bla U2OS receptor cells. The functional studies revealed that HBK-17 relative to serotonin moderately activated $B$-arrestin recruitment in $5-\mathrm{HT}_{1 \mathrm{~A}}$ receptor (Table 3). As presented in Table 3 the efficacy of HBK-17 $\left(E_{\max }=94 \%\right)$ was similar relative to that induced by $10 \mu \mathrm{mol} \mathrm{L}^{-1}$ serotonin $\left(E_{\max }=100 \%\right)$, but the potency was 4.4 -fold lower. In the antagonist mode, HBK-17 did not show any effect in this assay.

Since stimulation of $5-\mathrm{HT}_{1 \mathrm{~A}}$ receptor may lead to the activation of the ERK/MAPK pathway, we determined the effect of HBK-17 on the level p-ERK1/2 using the CHO-5HT1A receptor cells. The compound showed partial agonistic properties in this assay. In the p-ERK1/2 assay, HBK-17 showed 6.6-fold 
TABLE 2 | Intrinsic activity of $\mathrm{HBK}-17$ toward 5- $\mathrm{HT}_{2 \mathrm{~A}}, 5-\mathrm{HT}_{7}$, and $\mathrm{D}_{2}$ receptors.

\begin{tabular}{|c|c|c|c|c|c|c|c|c|c|}
\hline \multirow[t]{2}{*}{ Receptor } & \multirow[t]{2}{*}{ Treatment } & \multicolumn{3}{|c|}{ Agonist mode* } & \multicolumn{5}{|c|}{ Antagonist mode** } \\
\hline & & $\mathrm{E}_{\max } \%$ & SEM & $\mathrm{pEC}_{50}$ & $E_{\max } \%$ & SEM & $\mathrm{plC}_{50}$ & $\mathrm{~K}_{\mathrm{b}}[\mathrm{nM}]$ & $\mathbf{R}^{2} \mathbf{K}_{\mathrm{b}}$ \\
\hline \multirow[t]{3}{*}{$5-\mathrm{HT}_{7}$} & Serotonin & $100 \%$ & 3.5 & 8.34 & $1 \%$ & 7.0 & n.c. & n.c. & n.c. \\
\hline & SB269970 & $4 \%$ & 3.5 & n.c. & $8 \%$ & 0.0 & 8.82 & 0.5 & 0.993 \\
\hline & $\mathrm{HBK}-17$ & $18 \%$ & 1.5 & n.c. & $11 \%$ & 0.0 & 6.91 & 39 & 0.919 \\
\hline \multirow[t]{3}{*}{$5-\mathrm{HT}_{2 \mathrm{~A}}$} & $\alpha$-Methylserotonin & $100 \%$ & 0.0 & 8.70 & $1 \%$ & 0.0 & n.c. & n.c. & n.c. \\
\hline & Pimavanserin & $1 \%$ & 0.5 & n.c. & $0 \%$ & 0.0 & 8.04 & 0.57 & 0.948 \\
\hline & $\mathrm{HBK}-17$ & $1 \%$ & 0.0 & n.c. & $58 \%$ & 3.0 & 4.95 & 700 & 0.932 \\
\hline \multirow[t]{3}{*}{$\mathrm{D}_{2}$} & Apomorphine & $100 \%$ & 2.0 & 7.89 & $1 \%$ & 0.5 & n.c. & n.c. & n.c. \\
\hline & Chlorpromazine & $5 \%$ & 2.5 & n.c. & $1 \%$ & 0.0 & 8.53 & 0.89 & 0.956 \\
\hline & HBK-17 & $2 \%$ & 0.0 & n.c. & $0 \%$ & 0.0 & 7.65 & 6.63 & 0.881 \\
\hline
\end{tabular}

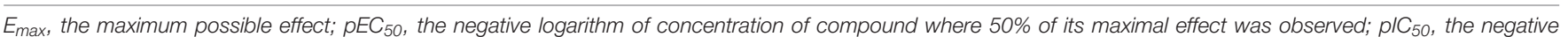

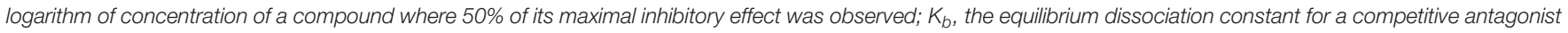

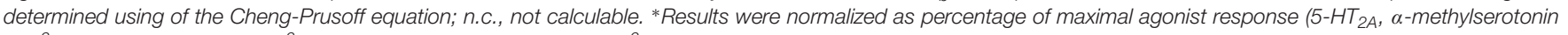
$10^{-6} \mathrm{M} ; 5-H T_{7}$, serotonin $10^{-6} \mathrm{M} ; \mathrm{D}_{2}$ receptors, apomorphine $\left.10^{-6} \mathrm{M}\right)$. $^{* *}$ Results were normalized as percentage of maximal response in the absence of antagonist.

TABLE 3 | Intrinsic activity of HBK-17 at 5- $\mathrm{HT}_{1 \mathrm{~A}}$ receptor in various functional assays.

\begin{tabular}{|c|c|c|c|c|c|c|c|c|c|}
\hline \multirow[t]{2}{*}{$5-\mathrm{HT}_{1 \mathrm{~A}}$ assay } & \multirow[t]{2}{*}{ Treatment } & \multicolumn{3}{|c|}{ Agonist mode* } & \multicolumn{5}{|c|}{ Antagonist mode** } \\
\hline & & $\mathrm{E}_{\max } \%$ & SEM & $\mathrm{pEC}_{50}$ & $E_{\max } \%$ & SEM & $\mathrm{plC}_{50}$ & $K_{b}[n M]$ & $\mathbf{R}^{2} \mathbf{K}_{\mathrm{b}}$ \\
\hline \multirow[t]{3}{*}{ CAMP } & Serotonin & 100 & 2.0 & 7.52 & 4 & 0.5 & n.c. & n.c. & n.c. \\
\hline & WAY-100135 & 2 & 0.5 & n.c. & 8 & 1.0 & 7.9 & 6.4 & 0.939 \\
\hline & $\mathrm{HBK}-17$ & 1 & 1.5 & n.c. & 4 & 1.0 & 6.8 & 39 & 0.894 \\
\hline \multirow[t]{3}{*}{ B-arrestin } & Serotonin & 100 & 0.5 & 7.13 & 2 & 1.0 & n.c & n.c. & n.c. \\
\hline & WAY-100135 & 1 & 0.5 & n.c. & 5 & 0.9 & 8.1 & 5.9 & 0.779 \\
\hline & $\mathrm{HBK}-17$ & 94 & 0.5 & 6.49 & 29 & 3.0 & n.c. & n.c. & n.c. \\
\hline \multirow[t]{3}{*}{ pERK1/2 } & Serotonin & 100 & 5.0 & 7.95 & 1 & 0.5 & n.c & n.c. & n.c. \\
\hline & WAY-100135 & 2 & 1 & n.c. & 0 & 0.0 & 7.90 & 2.7 & 0.769 \\
\hline & HBK-17 & 40 & 1.5 & 7.85 & 35 & 0.9 & 6.7 & 29 & 0.836 \\
\hline \multirow[t]{3}{*}{$\mathrm{Ca}^{2+}$} & Serotonin & $100^{a}$ & $1.0^{a}$ & $6.50^{a}$ & 1 & 0.0 & n.c. ${ }^{a}$ & n.c. ${ }^{a}$ & n.c. ${ }^{a}$ \\
\hline & WAY-100135 & 2 & 0 & n.c. & 0 & 0.0 & 8.3 & 0.8 & 0.997 \\
\hline & HBK-17 & $1^{a}$ & $0.0^{a}$ & n.c. $c^{a}$ & $4^{a}$ & $0.0^{a}$ & $8^{a}$ & $6.9^{a}$ & $0.907^{a}$ \\
\hline
\end{tabular}

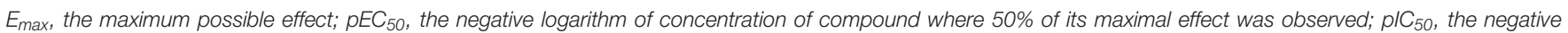

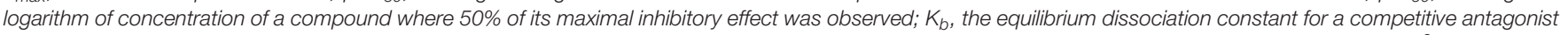

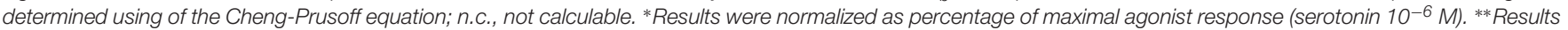
were normalized as percentage of maximal response in the absence of antagonist. a Kubacka et al. (2016).

higher potency than serotonin, but 2.5-fold lower efficacy (Table 3). In the antagonist mode HBK-17, compared with the reference antagonist, WAY-100135, showed 10.7-fold lower $\mathrm{K}_{\mathrm{b}}$ value.

Our previous studies demonstrated that in the $\mathrm{Ca}^{2+}$ mobilization assay the reference compound, WAY-100135, showed strong antagonistic properties (Table 3; Kubacka et al., 2016).

\section{HBK-17 Increased the Number of Punished Crossings in the Four Plate Test and Did Not Affect the Pain Response in the Hot Plate Test in Mice}

In order to evaluate the anxiolytic-like properties of the compound, we performed four plate test in mice. The tested compound HBK-17 at a dose $5 \mathrm{mg} / \mathrm{kg}$ (but not 1.25, 2.5,
10 , or $20 \mathrm{mg} / \mathrm{kg}$ ) significantly increased the number of punished crossings by $70.9 \%$ compared with non-treated control $[F(5,54)=3.791, p<0.01]$ (Figure 2A). A reference $5-\mathrm{HT}_{1 \mathrm{~A}}$ receptor agonist, 8-OD-DPAT, at a dose $0.5 \mathrm{mg} / \mathrm{kg}$ (but not $0.25,1$ or $2 \mathrm{mg} / \mathrm{kg}$ ) significantly increased the number of punished crossings by 38.2\% $[F(4,37)=3.791, p<0.05]$ (Figure 2C). Another reference compound SB269970, a 5- $\mathrm{HT}_{7}$ receptor antagonist, at a dose $2.5 \mathrm{mg} / \mathrm{kg}$ (but not 1.25 or $5 \mathrm{mg} / \mathrm{kg}$ ) increased the number of punished crossings by $137.5 \%$ compared with non-treated control $[F(3,29)=5.903$, $p<0.01]$ (Figure 2D). Compounds with analgesic properties might show false positive results in the four plate test. Therefore, we evaluated the HBK-17 influence on pain responses in the hot plate test in mice. HBK-17 at doses $1.25-20 \mathrm{mg} / \mathrm{kg}$ did not increase the latency time to the first hind paw or/and jumping response $[F(5,54)=0.466$, ns $]$ (Figure 2B). 


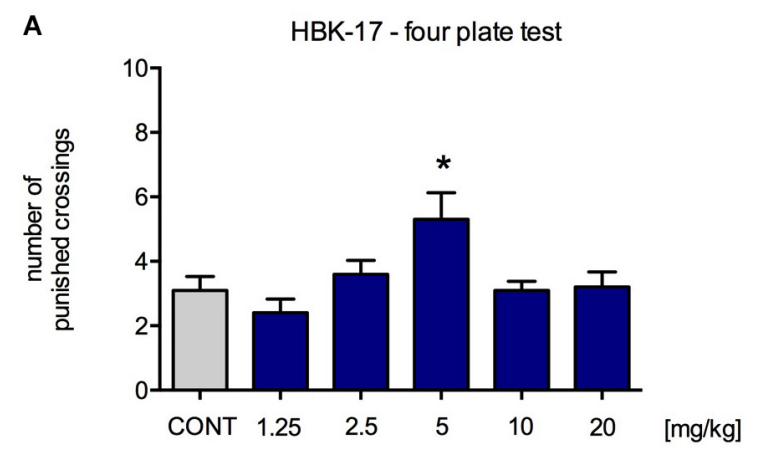

C
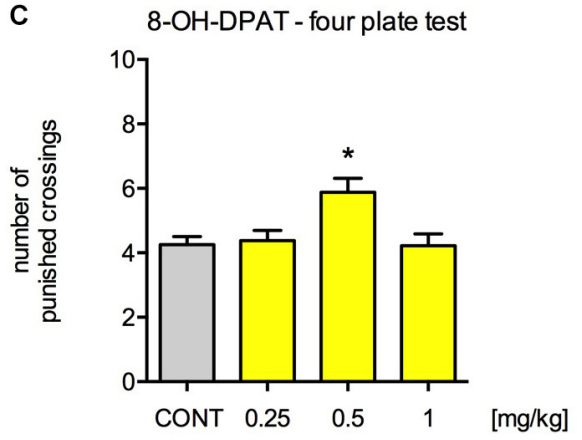

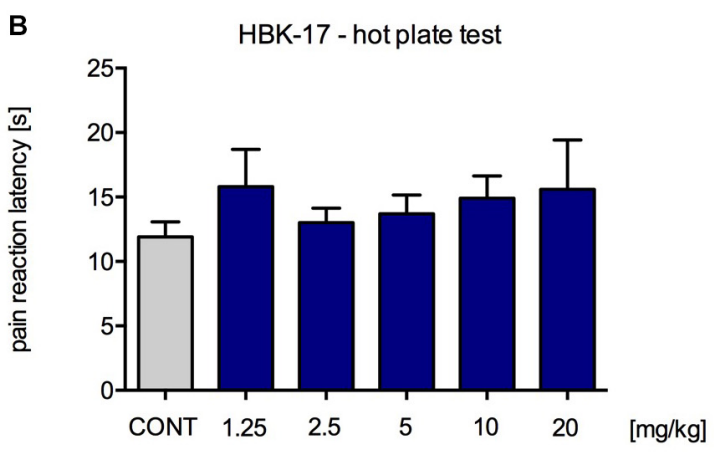

。

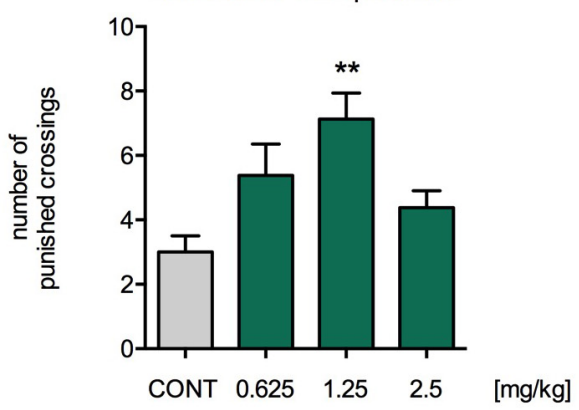

FIGURE 2 | The effect of HBK-17 (A), 8-OH-DPAT (C), and SB 269970 (D) on the behavior of mice in the four plate test and the influence of HBK-17 on the pain threshold (B). HBK-17 and SB 269970 were administered intraperitoneally 30 min before the experiment, whereas 8 -OH-DPAT was injected 15 min before the four plate test. CONT - control group; Statistical analysis: one-way ANOVA (Newman-Keuls post hoc) ${ }^{*} p<0.05,{ }^{* *} p<0.01$ vs. control group; $n=8-10$ mice per group.

\section{HBK-17 Increased the Time in the Open Arms and Open Arm Entries in the Elevated Plus Maze Test in Mice}

To confirm our findings, we performed another experiment assessing anxiolytic-like properties of the compound, i.e., elevated plus maze test. HBK-17 at a dose $5 \mathrm{mg} / \mathrm{kg}$ (but not $1.25,2.5,10$, or $20 \mathrm{mg} / \mathrm{kg}$ ) compared with non-treated control significantly increased the time spent in the open arms by $38.9 \%[F(5,54)=4.143, p<0.01]$ and the number of open arm entries by $28.6 \%[F(5,54)=5.267, p<0.01]$ (Figures 3A,B). 8-OH-DPAT at a dose $2 \mathrm{mg} / \mathrm{kg}$ (but not $0.25,0.5$ or $1 \mathrm{mg} / \mathrm{kg}$ ) compared with non-treated control significantly increased the time spent in the open arms by $154.3 \%[F(3,29)=3.710, p<0.05]$ but had no effect on the number of open arm entries $[F(3,29)=2.224$, ns] (Figures 3C,D). SB269970 at a dose $2.5 \mathrm{mg} / \mathrm{kg}$ (but not 1.25 or $5 \mathrm{mg} / \mathrm{kg}$ ) compared with non-treated control significantly increased the time spent in the open arms by $76.4 \%[F(3,28)=3.026$, $p<0.05]$ and the number of open arm entries by $48.6 \%$ $[F(3,30)=3.396, p<0.05]$ (Figures 3E,F). Diazepam at the doses 1.25 and $2.5 \mathrm{mg} / \mathrm{kg}$ (but not 0.3125 or $0.625 \mathrm{mg} / \mathrm{kg}$ ) compared with non-treated control significantly increased the time spent in the open arms by 84.6 and $59.9 \%[F(4,35)=12.870$, $p<0.0001]$, respectively. The reference compound significantly increased the number of open arm entries at the doses $0.625,1.25$, and $2.5 \mathrm{mg} / \mathrm{kg}$ (but not $0.3125 \mathrm{mg} / \mathrm{kg}$ ) by 78.5 ,
73.9, and $124.6 \%[F(4,35)=5.908, p<0.01]$, respectively (Figures 3G,H).

\section{No Effect of HBK-17 After Pretreatment With pCPA or WAY-100635, But Not AMPT, in the Four Plate Test in Mice}

To find the possible mechanism of anxiolytic-like activity of HBK-17, we again performed the four plate test, but this time using tryptophan hydroxylase inhibitor ( $\mathrm{pCPA}$ ), tyrosine hydroxylase inhibitor (AMPT), and $5-\mathrm{HT}_{1 \mathrm{~A}}$ receptor antagonist (WAY-100635), which would show the involvement of the serotonergic system, noradrenergic system, and the $5-\mathrm{HT}_{1 \mathrm{~A}}$ receptor, respectively. HBK-17 (5 mg/kg) significantly increased number of punished crossings of mice by $84.2 \%$ compared with non-treated control group. Three days treatment with pCPA (200 $\mathrm{mg} / \mathrm{kg}$ ) did not influence the measured parameter but abolished the activity of HBK-17 (Figure 4A). The two-way ANOVA demonstrated no effect of pCPA $[F(1,28)=0.887$; ns $]$, significant effect of HBK-17 $[F(1,28)=7.986 ; p<0.01]$, and significant interaction $[F(1,28)=4.831 ; p<0.05]$. Similarly, the administration of HBK-17 (5 mg/kg) increased the number of punished crossings by $60.0 \%$ compared with non-treated control group. Pretreatment with WAY-100635 $(0.3 \mathrm{mg} / \mathrm{kg})$ did not influence the number of punished crossings, but it antagonized the effect of HBK-17 (Figure 4B). The two-way ANOVA demonstrated no effect of WAY-100635 $[F(1,28)=3.092$; ns $]$, 


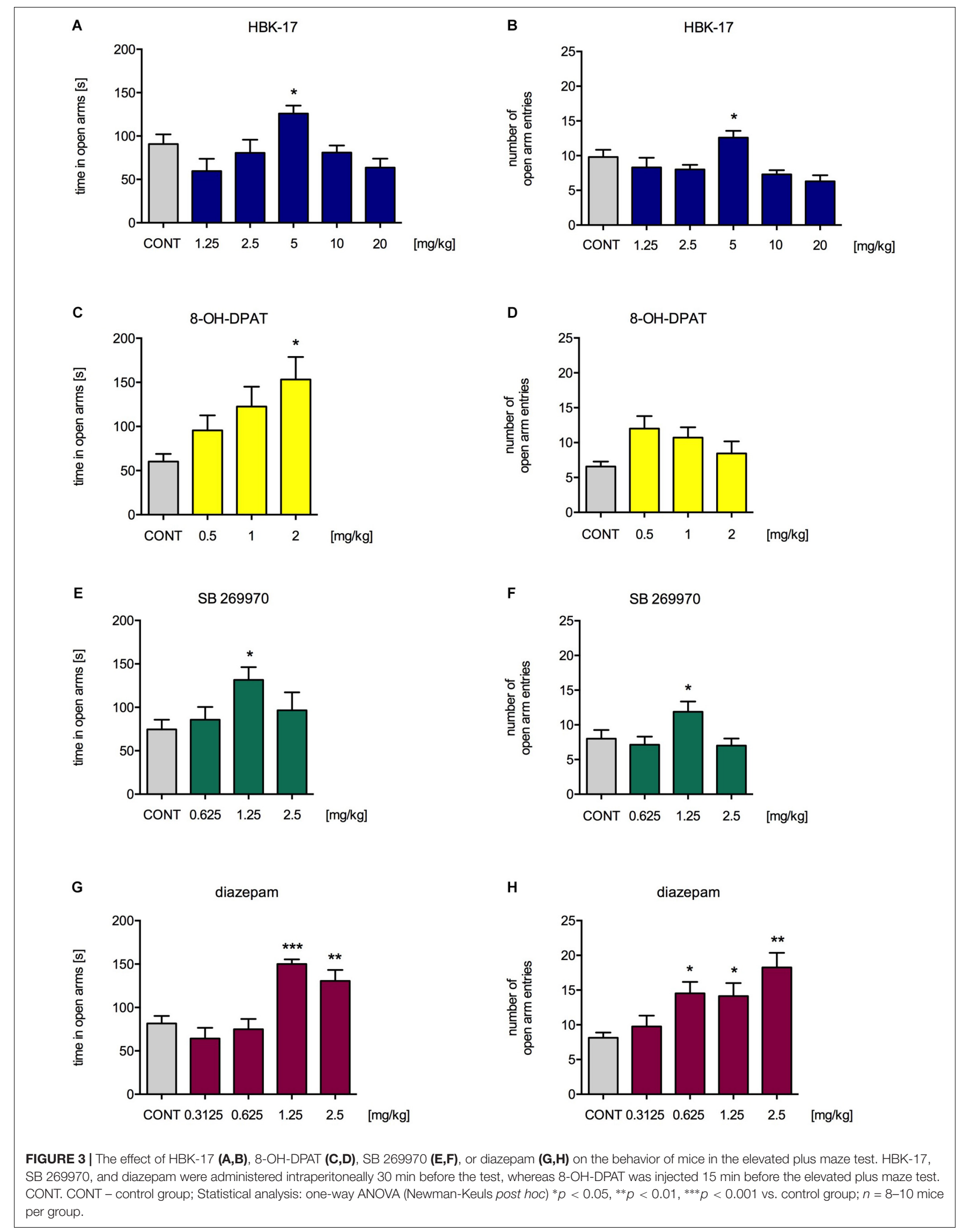


A

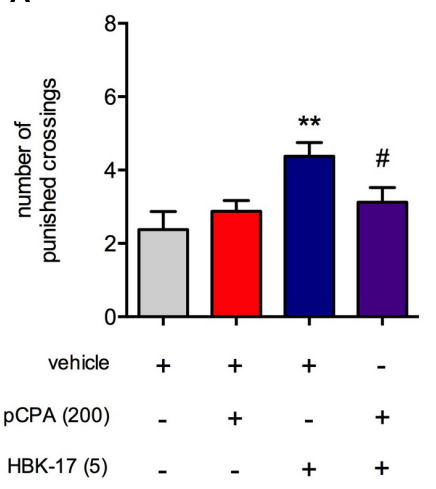

B

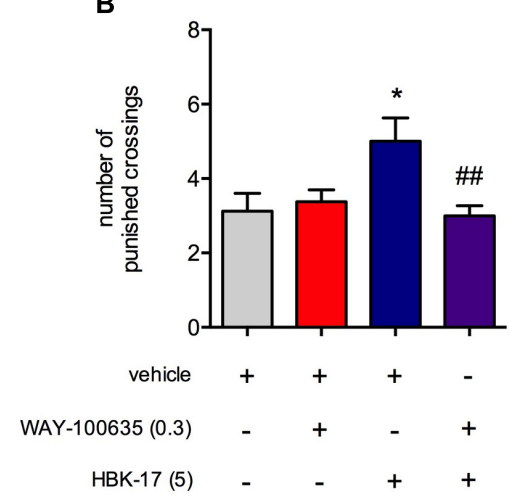

C

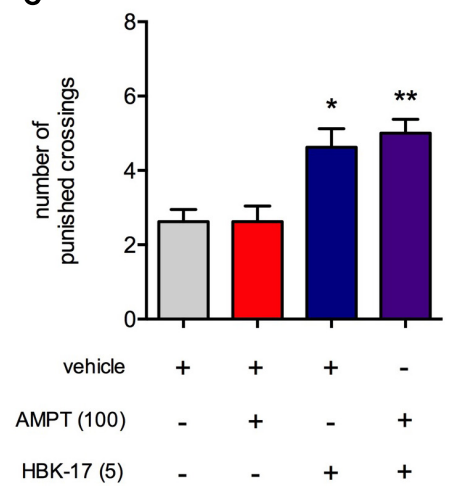

FIGURE 4 | The effect of p-chlorophenylalanine [pCPA, (A)], WAY-100635 (B), or $\alpha$-methylphenylalanine [AMPT, (C)] on anxiolytic-like activity of HBK-17 in the four plate test in mice. pCPA was injected intraperitoneally (i.p.) once daily for three consecutive days. Twenty-four hour after the last injection and 30 min before the test mice received (i.p.) either HBK-17 or $0.9 \%$ NaCl. WAY-100635 was administered subcutaneously 15 min before HBK-17. AMPT was injected (i.p.) 4 h before HBK-17. Vehicle-treated groups received $1 \%$ Tween (i.p.). Statistical analysis: two-way ANOVA (Bonferroni post hoc); ${ }^{*} p<0.05,{ }^{* *} p<0.01$ vs. respective control group receiving 1\% Tween; ${ }^{\#} p<0.05,{ }^{\# \#} p<0.01$ vs. respective group receiving HBK-17 at the dose $5 \mathrm{mg} / \mathrm{kg} ; n=8 \mathrm{mice}$ per group.

significant effect of HBK-17 $[F(1,28)=4.209 ; p<0.05]$, and significant interaction $[F(1,28)=8.589 ; p<0.01]$. The injection of HBK-17 (5 mg/kg) caused a significant increase by $76 \%$ in the number punished crossings, while AMPT (100 mg/kg) had no effect on this parameter. Pretreatment with AMPT did not influence the effect of HBK-17 (Figure 4C) in this test. The two-way ANOVA showed no effect of AMPT $[F(1,28)=0.209$; ns], significant effect of HBK-17 [ $F(1,28)=28.490 ; p<0.05]$, and no significant interaction $[F(1,28)=0.209 ; \mathrm{ns}]$.

\section{Neither HBK-17 Alone nor Co-Administered With PCPA, AMPT or WAY-100635 Affected Locomotor Activity in Mice}

To investigate whether the observed increased number of punished crossings was not due to psychostimulant properties, we evaluated the effect of HBK-17 on locomotor activity of mice in the 1-min session. The compound did not influence the locomotor activity of mice at the doses $1.25-20 \mathrm{mg} / \mathrm{kg}$ during the 1 -min session $[F(5,42)=2.616$; ns] (Table 4). To exclude false positive results in the elevated plus maze test, we also evaluated the effect of HBK-17 on locomotor activity of mice in 5-min session. The compound did not influence the locomotor activity of mice at the doses $1.25-20 \mathrm{mg} / \mathrm{kg}$ during the 5 -min session $[F(5,42)=2.485$; ns] (Table 4). Neither HBK-17 alone nor in combinations with pCPA or AMPT influenced the locomotor activity of mice (Table 4). The two-way ANOVA demonstrated no effect of pCPA $[F(1,28)=0.405 ; n s]$, no effect of HBK-17 $[F(1,28)=0.192 ; n s]$, and no significant interaction $[F(1,28)=1.001 ; n s]$. In case of AMPT the two-way ANOVA showed no effect of AMPT $[F(1,28)=0 ; n s]$, no effect of HBK-17 $[F(1,28)=0.026 ; n s]$, and no significant interaction $[F(1,28)=1.224$; ns $]$. The administration of HBK-17, WAY-100635 or the combination of both, did not affect the locomotor activity of mice (Table 4). The two-way ANOVA demonstrated no effect of WAY-100635 $[F(1,28)=1.452 ; n s]$, no effect of HBK-17 $[F(1,28)=0.088 ; n s]$, and no significant interaction $[F(1,28)=1.316$; ns $]$.

\section{Pharmacokinetic Study and Bioavailability}

We used a well-validated UPLC-MS/MS method to determine pharmacokinetic parameters after i.v. and i.p. administration of $\mathrm{HBK}-17$ at a dose of $5 \mathrm{mg} / \mathrm{kg}$ in mice. The parameters for the compound are presented in Table 5. HBK-17 was eliminated rather fast (i.v.: $t_{1 / 2}=105 \mathrm{~min}$; i.p.: $t_{1 / 2}=150 \mathrm{~min}$ ). The absorption of the compound after i.p. administration was also fast $\left(t_{\max }=5 \mathrm{~min}\right)$ with the maximum plasma concentration at $806.7 \mathrm{ng} / \mathrm{mL}$. The volume of distribution was $9.7 \mathrm{~L} / \mathrm{kg}$, suggesting the distribution of the compound throughout the total body water. The absolute bioavailability after i.p. administration, which was estimated based on the AUC $_{0 \rightarrow \infty}$ calculated from zero time to infinity, was significant $(F=44.8 \%)$.

HBK-17 distributed widely and rapidly in the brain within the time course examined. Thus, we can conclude that the compound penetrated the blood-brain barrier. We detected the highest concentrations of HBK-17 5 min after i.p. administration. The compound's concentration in the brain decreased significantly within $8 \mathrm{~h}$, which suggests that HBK-17 not tend to accumulate. The AUC ratio between brain and plasma was 1.13 and 0.96 after i.v. or i.p. administration revealed a satisfactory binding affinity to mice brain. The other parameters were as follows: $\mathrm{AUC}_{0 \rightarrow \infty}=23860 \mathrm{ng} \cdot \mathrm{min} / \mathrm{g}, \mathrm{MRT}=147.1 \mathrm{~min}$, $C_{\text {max }}=523.8 \mathrm{ng} / \mathrm{g}, t_{\max }=5 \mathrm{~min}$.

\section{DISCUSSION}

We found that HBK-17 possessed anxiolytic-like activity in mice, which depended on the $5-\mathrm{HT}_{1 \mathrm{~A}}$ receptor activation. After 
TABLE 4 | The influence of HBK-17 and its combinations with pCPA, AMPT, or WAY-100635 on locomotor activity of mice.

\begin{tabular}{|c|c|c|c|c|}
\hline \multirow{2}{*}{$\begin{array}{l}\text { Treatment } \\
\text { Vehicle }\end{array}$} & \multirow{2}{*}{$\begin{array}{c}\text { Dose [mg/kg] } \\
-\end{array}$} & \multicolumn{3}{|c|}{ Number of crossings \pm SEM } \\
\hline & & 36.0 & \pm & 8.3 \\
\hline & 1.25 & 32.6 & \pm & 4.7 \\
\hline $\mathrm{HBK}-17$ & 2.5 & 35.6 & \pm & 6.6 \\
\hline \multirow[t]{3}{*}{ (1-min session) } & 5 & 44.8 & \pm & 8.4 \\
\hline & 10 & 59.3 & \pm & 6.4 \\
\hline & 20 & 31.3 & \pm & 3.2 \\
\hline \multirow[t]{2}{*}{ Vehicle } & - & 323.4 & \pm & 53.7 \\
\hline & 1.25 & 295.6 & \pm & 20.4 \\
\hline HBK-17 & 2.5 & 326.1 & \pm & 19.5 \\
\hline \multirow[t]{3}{*}{ (5-min session) } & 5 & 317.0 & \pm & 24.5 \\
\hline & 10 & 289.9 & \pm & 19.5 \\
\hline & 20 & 204.8 & \pm & 19.1 \\
\hline Vehicle & - & 41.8 & \pm & 9.9 \\
\hline HBK-17 & 5 & 30.9 & \pm & 7.6 \\
\hline pCPA & 200 & 29.4 & \pm & 6.8 \\
\hline $\mathrm{HBK}-17+\mathrm{pCPA}$ & $5+200$ & 33.6 & \pm & 5.0 \\
\hline Vehicle & - & 33.1 & \pm & 7.1 \\
\hline $\mathrm{HBK}-17$ & 5 & 23.3 & \pm & 3.9 \\
\hline AMPT & 100 & 24.5 & \pm & 7.3 \\
\hline HBK-17 + AMPT & $5+100$ & 31.9 & \pm & 8.5 \\
\hline Vehicle & - & 48.3 & \pm & 5.9 \\
\hline HBK-17 & 5 & 41.1 & \pm & 9.9 \\
\hline WAY-100635 & 0.3 & 27.9 & \pm & 7.8 \\
\hline HBK-17 + WAY-100635 & $5+0.3$ & 40.4 & \pm & 9.9 \\
\hline
\end{tabular}

HBK-17 was administered intraperitoneally (i.p.) 30 min before the test. pCPA was injected intraperitoneally (i.p.) once daily for three consecutive days. Twenty-four hour after the last injection and $30 \mathrm{~min}$ before the test mice received (i.p.) either $\mathrm{HBK}-17$ or $0.9 \% \mathrm{NaCl}$. WAY-100635 was administered subcutaneously $15 \mathrm{~min}$ before HBK-17. AMPT was injected (i.p.) $4 \mathrm{~h}$ before HBK-17. Vehicle-treated groups received $0.9 \% \mathrm{NaCl}$ (i.p.). Statistical analysis: one-way ANOVA (Newman-Keuls post hoc; in case of HBK-17 administered alone) or two-way ANOVA (Bonferroni post hoc; in case of combined treatments); $n=8$ mice per group.

binding to the $5-\mathrm{HT}_{1 \mathrm{~A}}$ receptor, the compound preferentially activated $\beta$-arrestin recruitment over $\mathrm{Ca}^{2+}$ mobilization, phosphorylation of ERK1/2 or cAMP formation inhibition. We also demonstrated that following a single i.v. or i.p. administration, HBK-17 showed relatively high bioavailability, rapid absorption to the blood but rather low distribution to the brain.

Serotonin $5-\mathrm{HT}_{1 \mathrm{~A}}$ and $5-\mathrm{HT}_{7}$ receptors play a role in anxiety (Żmudzka et al., 2018). Studies proved that both stimulation and blockade of $5-\mathrm{HT}_{1 \mathrm{~A}}$ and the blockade of $5-\mathrm{HT}_{7}$ receptors might cause anxiolytic-like effects (Garcia-Garcia et al., 2014; Nikiforuk, 2015). Since HBK-17 showed affinity for both $5-\mathrm{HT}_{1 \mathrm{~A}}$ and $5-\mathrm{HT}_{7}$ receptors, it might also influence anxiety-like behaviors. Thus, as the first step of our studies, we investigated the compound's anxiolytic-like properties using a preliminary assay based on the unconditioned fear model of anxiety, i.e., the four plate test in mice. Our results show that the compound possessed significant anxiolytic-like activity at one dose tested $(5 \mathrm{mg} / \mathrm{kg})$. Since HBK-17 did not influence pain responses and locomotor activity of mice, we can conclude that the obtained results were specific to anxiety.
TABLE 5 | Pharmacokinetic parameters for HBK-17 after i.v. and i.p administration at a dose of $5 \mathrm{mg} / \mathrm{kg}$ to mice.

\begin{tabular}{lcc}
\hline & \multicolumn{2}{c}{ Parameters } \\
\cline { 2 - 3 } & i.v. & i.p. \\
\hline $\mathrm{C}_{0}[\mathrm{ng} / \mathrm{mL}]$ & 1482 & - \\
$\mathrm{A} \cup \mathrm{C}_{0 \rightarrow \infty}[\mathrm{ng} \cdot \mathrm{min} / \mathrm{mL}]$ & 55558 & 24877 \\
$\mathrm{MRT}[\mathrm{min}]$ & 107.9 & 101.4 \\
$\mathrm{t}_{0.5}[\mathrm{~min}]$ & 105.4 & 149.9 \\
$\mathrm{C}_{\max }[\mathrm{ng} / \mathrm{mL}]$ & - & 806.7 \\
$\mathrm{t}_{\max }[\mathrm{min}]$ & - & 5 \\
$V_{d}[\mathrm{~L} / \mathrm{kg}]$ & 13683.6 & - \\
$\mathrm{Cl}[\mathrm{L} / \mathrm{min} / \mathrm{kg}]$ & 90 & \\
$\mathrm{~F}[\%]$ & & 44.8 \\
\hline
\end{tabular}

$C_{0}$, the initial concentration; $C_{\text {max }}$, the maximum plasma concentration; $t_{\max }$, time to reach the maximum plasma concentration; $t_{1 / 2}$, terminal half-life; MRT, mean residence time; $A \cup C_{0 \rightarrow \infty}$, area under the concentration-time curve from zero up to infinitive time; $\mathrm{Cl}$, systemic clearance; $V_{d}$, volume of distribution; $F$, bioavailability.

Next, we decided to confirm our findings in another experiment, i.e., the elevated plus maze, which uses a natural aversion of rodents for open and elevated areas. Compounds with anxiolytic-like properties increase the time spent and the number of entries to the open arms of the elevated plus maze. Similarly, the administration of HBK-17 at only one dose $(5 \mathrm{mg} / \mathrm{kg})$ increased the time spent and the number of entries in the open arms of the elevated plus maze. The compound did not affect the locomotor activity of mice; thus, the observed effect could not be attributed to psychostimulant properties. In our previous experiments, HBK-17 showed strong antiarrhythmic properties in adrenaline-induced arrhythmia in rats (Pytka et al., 2016a). Anxiety disorder patients often report autonomic manifestations of anxiety, such as increased heart rate or blood pressure (Gałuszka, 2013). These factors also determine anxiety levels in animals (Pattij, 2002). The fact that HBK-17 normalized heart rhythm in adrenaline-induced arrhythmia might complement its anxiolytic-like effect.

Interestingly, in both behavioral tests, HBK-17 showed an inverted U-shaped dose-effect (only one dose was active). A similar dose-effect function was demonstrated for a reference compound, a selective 5- $\mathrm{HT}_{7}$ receptor antagonist, SB 269970 and a $5-\mathrm{HT}_{1 \mathrm{~A}}$ receptor agonist, $8-\mathrm{OH}$-DPAT in the four plate test. In the elevated plus maze test the only active dose of 8-OH-DPAT was the highest dose tested (i.e., $2 \mathrm{mg} / \mathrm{kg}$ ). Conversely, a well-known anxiolytic, diazepam, showed a dose dependent-effect in both tests (Pytka et al., 2015a). Although scientists very often report such a non-linear relationship in pharmacological studies (Baldi and Bucherelli, 2005), an inverted U-shaped dose-effect it is very poorly understood. Some scientists suggest that this effect might have multifactorial nature, which is difficult to explain. In the case of HBK-17, there might be an explanation of this phenomenon. The anxiolytic-like effect of HBK-17 at higher doses might disappear due to the sedative properties of the compound, which we reported in our previous studies $\left(\mathrm{ED}_{50}=15.0 \mathrm{mg} / \mathrm{kg}\right.$, observation time: $30 \mathrm{~min}$ ) (Waszkielewicz et al., 2015). It is also possible that as HBK-17, 8-OH-DPAT, and SB 269970 showed an inverted 
U-shaped dose-effect, this might be a common feature of serotonin agents.

Toward a better understanding of the pharmacological properties of $\mathrm{HBK}-17$, we evaluated the compound's affinity for $G_{A B A}$, adrenergic $\alpha_{2}$ and dopamine $D_{2}$ receptors. The studied compound showed a moderate affinity for $\mathrm{D}_{2}$ receptors, whereas no affinity for $\mathrm{GABA}_{\mathrm{A}}$ and $\alpha_{2}$ receptors. Our previous studies demonstrated that HBK-17 showed high affinity for $\alpha_{1}$ (Pytka et al., 2016a) and 5-HT7 (Waszkielewicz et al., 2015), moderate for $5-\mathrm{HT}_{2 \mathrm{~A}}$ (Kubacka et al., 2016), and very low for 5- $\mathrm{HT}_{6}$ and $5-\mathrm{HT}_{3}$ receptors (Waszkielewicz et al., 2015; Kubacka et al., 2016). Bearing that in mind, we evaluated the compound's intrinsic activity at $5-\mathrm{HT}_{2} \mathrm{~A}, 5-\mathrm{HT}_{7}$, and $\mathrm{D}_{2}$ receptors. Our functional studies indicated that $\mathrm{HBK}-17$ was a moderate $\mathrm{D}_{2}$ and very weak $5-\mathrm{HT}_{7}$ receptors antagonist.

In our previous experiments, HBK-17 showed antagonistic properties at $5-\mathrm{HT}_{1 \mathrm{~A}}$ receptor $\left(\mathrm{Ca}^{2+}\right.$ mobilization assay), in this study we demonstrated that the compound showed functional selectivity at the $5-\mathrm{HT}_{1 \mathrm{~A}}$ receptor. It preferentially activated $\beta$-arrestin recruitment vs. $\mathrm{p}$-ERK1/2, cAMP production inhibition or $\mathrm{Ca}^{2+}$ mobilization. Interestingly, HBK-17 showed partial agonistic activity in the p-ERK1/2 assay. Studies demonstrated decreased ERK expression and phosphorylation in post-mortem brains of depressed patients (suicide victims) (Dwivedi et al., 2001). Similar changes were observed in animal models of depression (Tiraboschi et al., 2004). Therefore, the fact that HBK-17 increased p-ERK1/2 might at least in part underlie its previously described antidepressant-like properties (Waszkielewicz et al., 2015; Kubacka et al., 2016). At this point, it is also worth mentioning that $ß$-arrestins desensitize not only G-protein-dependent signal pathways but also promote novel pathways of signal transduction, e.g., ERK, JNK, p38, or Akt (for review see DeWire et al., 2007). Thus, it might be possible that the observed increase in p-ERK1/2 might also be a result of the activation of $\beta$-arrestin recruitment. Nevertheless, we need to perform more experiments to explain this issue.

To find the possible mechanism of anxiolytic-like activity of HBK-17, we performed another set of experiments, i.e., pretreated mice with pCPA (tryptophan hydroxylase inhibitor), WAY-100635 (non-selective $5-\mathrm{HT}_{1 \mathrm{~A}}$ receptor antagonist), or AMPT (tyrosine hydroxylase inhibitor). Imaizumi et al. (1996) demonstrated that a 3 -day treatment with pCPA $(200 \mathrm{mg} / \mathrm{kg})$ significantly reduced serotonin levels in the cortex $(30 \%)$, diencephalon (35\%), midbrain $(24 \%)$, and pons with medulla (34\%). The depletion of serotonin levels by pCPA abolished the anxiolytic-like activity of HBK-17 in the four plate test. We observed a similar effect after pretreatment with WAY-100635, which implies that the anxiolytic-like activity of HBK-17 depended on the activation of the serotonergic system, and particularly $5-\mathrm{HT}_{1 \mathrm{~A}}$ receptors. In contrast, AMPT did not affect the compound's activity in this test. This suggests that noradrenergic and dopaminergic systems are not involved in HBK-17 anxiolytic-like activity. We speculate that the anxiolytic-like activity of HBK-17 might have been a result of the postsynaptic $5-\mathrm{HT}_{1 \mathrm{~A}}$ receptors internalization induced by the recruitment of $B$-arrestins and possibly the stimulation of presynaptic receptors. Nonetheless, our hypothesis requires confirmation.

Pharmacokinetic parameters of the compound influence its pharmacological activity. Thus, we evaluated the pharmacokinetic profile of HBK-17. We demonstrated that HBK-17 was rapidly absorbed with the peak concentration occurring after $5 \mathrm{~min}$ and had a rather long half-life of about 105 and $150 \mathrm{~min}$ when administered i.v. or i.p., respectively. The volume of distribution $(9.7 \mathrm{~L} / \mathrm{kg})$ suggests that the compound was moving throughout the body water. We should emphasize the relatively high bioavailability $(44.8 \%)$ of the studied compound. HBK-17 could penetrate the brain tissue with the brain/plasma ratio of 1.13 and 0.96 after i.v. or i.p. administration, respectively. The results show that we could administer the compound by both i.v. and i.p. routes. Therefore, we conclude that HBK-17 has a desirable pharmacokinetic profile for pharmacological studies. Moreover, to our knowledge, this is the first report to quantify HBK-17 in biomatrices and assess its pharmacokinetics in mice.

\section{CONCLUSION}

We demonstrated that HBK-17 possessed anxiolytic-like activity in mice, which depended on the $5-\mathrm{HT}_{1 \mathrm{~A}}$ receptor activation. The compound after binding to the $5-\mathrm{HT}_{1 \mathrm{~A}}$ receptor preferentially activated $\beta$-arrestin recruitment over $\mathrm{Ca}^{2+}$ mobilization, phosphorylation of ERK1/2 or cAMP formation inhibition. We also demonstrated that following a single i.v. or i.p. administration, HBK-17 showed relatively high bioavailability, rapid absorption to the blood but rather low distribution to brain. The interesting pharmacological profile of HBK-17 encourages further experiments to understand its mechanism of action fully.

\section{AUTHOR CONTRIBUTIONS}

KPy, JS, BF, and MK conceived and designed the experiments. KPy, MG-L, KN, AS, MS, KPa, EŻ, and KS performed the experiments. KPy, MG-L, MW, AS, AO, AG, and JŚ analyzed the data. MK, KPy, AW, and HM contributed to reagents, materials, and analysis tools. KPy, MG-L, KS, EŻ, MW, AS, and AW wrote the paper.

\section{FUNDING}

This study was supported by Jagiellonian University grant numbers: K/DSC/001955, K/DSC/004285, and K/ZDS/006223, and partially by Students Scientific Association grant number: GS 15/14 UJ, The National Science Centre (NCN) grant numbers: DEC- 2013/11/B/ST7/01713, 2017/01/X/NZ7/00818, and 2015/19/B/NZ7/03543, and Silesian University of Technology BK grant number: 02/010/BK18/0102.

\section{ACKNOWLEDGMENTS}

We wish to thank Agnieszka Niedbał and Teresa Dobrut for their technical assistance. 


\section{REFERENCES}

Akimova, E., Lanzenberger, R., and Kasper, S. (2009). The serotonin-1A receptor in anxiety disorders. Biol. Psychiatry 66, 627-635. doi: 10.1016/j.biopsych.2009. 03.012

Aron, C., Simon, P., Larousse, C., and Boissier, J. R. (1971). Evaluation of a rapid technique for detecting minor tranquilizers. Neuropharmacology 10, 459-469. doi: 10.1016/0028-3908(71)90074-8

Baldi, E., and Bucherelli, C. (2005). The inverted "u-shaped" dose-effect relationships in learning and memory: modulation of arousal and consolidation. Nonlinearity Biol. Toxicol. Med. 3, 9-21. doi: 10.2201/ nonlin.003.01.002

Bourin, M., Masse, F., Dailly, E., and Hascoët, M. (2005). Anxiolytic-like effect of milnacipran in the four-plate test in mice: mechanism of action. Pharmacol. Biochem. Behav. 81, 645-656. doi: 10.1016/j.pbb.2005.04.015

Cervo, L., Mocaër, E., Bertaglia, A., and Samanin, R. (2000). Roles of 5-HT1A receptors in the dorsal raphe and dorsal hippocampus in anxiety assessed by the behavioral effects of 8-OH-DPAT and S 15535 in a modified GellerSeifter conflict model. Neuropharmacology 39, 1037-1043. doi: 10.1016/s00283908(99)00189-6

Cheng, Y., and Prusoff, W. H. (1973). Relationship between the inhibition constant (K1) and the concentration of inhibitor which causes 50 per cent inhibition (I50) of an enzymatic reaction. Biochem. Pharmacol. 22, 3099-3108. doi: 10. 1016/0006-2952(73)90196-2

Chilmonczyk, Z., Bojarski, A. J., Pilc, A., and Sylte, I. (2015). Functional selectivity and antidepressant activity of serotonin $1 \mathrm{~A}$ receptor ligands. Int. J. Mol. Sci. 16, 18474-18506. doi: 10.3390/ijms160818474

Collinson, N., and Dawson, G. R. (1997). On the elevated plus-maze the anxiolyticlike effects of the 5-HT 1A agonist, 8-OH-DPAT, but not the anxiogenic-like effects of the 5-HT 1A partial agonist, buspirone, are blocked by the 5-HT 1A antagonist, WAY 100635. Psychopharmacology 132, 35-43. doi: 10.1007/ s002130050317

De Almeida, R. M., Giovenardi, M., Charchat, H., and Lucion, A. B. (1998). 8-OHDPAT in the median raphe nucleus decreases while in the medial septal area it may increase anxiety in female rats. Neurosci. Biobehav. Rev. 23, 259-264. doi: 10.1016/S0149-7634(98)00026-8

DeWire, S. M., Ahn, S., Lefkowitz, R. J., and Shenoy, S. K. (2007). Beta-arrestins and cell signaling. Annu. Rev. Physiol. 69, 483-510. doi: 10.1146/annurev.ph.69. 013107.100021

Dwivedi, Y., Rizavi, H. S., Roberts, R. C., Conley, R. C., Tamminga, C. A., and Pandey, G. N. (2001). Reduced activation and expression of ERK1/2 MAP kinase in the post-mortem brain of depressed suicide subjects. J. Neurochem. 77, 916-928. doi: 10.1046/j.1471-4159.2001.00300.x

File, S. E., Gonzalez, L. E., and Andrews, N. (1996). Comparative study of pre- and postsynaptic 5-HT1A receptor modulation of anxiety in two ethological animal tests. J. Neurosci. 16, 4810-4815. doi: 10.1523/JNEUROSCI.16-15-04810.1996

Gałuszka, A. (2013). Personality and social resources in case of serious somatic disease. Psychol. Health 28, 217-217.

Garcia-Garcia, A. L., Newman-Tancredi, A., and Leonardo, E. D. (2014). 5-HT(1A) [corrected] receptors in mood and anxiety: recent insights into autoreceptor versus heteroreceptor function. Psychopharmacology 231, 623-636. doi: 10. 1007/s00213-013-3389-x

Heisler, L. K., Chu, H. M., Brennan, T. J., Danao, J. A., Bajwa, P., Parsons, L. H., et al. (1998). Elevated anxiety and antidepressant-like responses in serotonin 5-HT1A receptor mutant mice. Proc. Natl. Acad. Sci. U.S.A. 95, 15049-15054. doi: 10.1073/pnas.95.25.15049

Iderberg, H., McCreary, A. C., Varney, M. A., Cenci, M. A., and NewmanTancredi, A. (2015). Activity of serotonin 5-HT1A receptor "biased agonists" in rat models of Parkinson's disease and 1-DOPA-induced dyskinesia. Neuropharmacology 93, 52-67. doi: 10.1016/j.neuropharm.2015.01.012

Imaizumi, M., Miyazaki, S., and Onodera, K. (1996). Effects of theophylline in p-chlorophenylalanine-treated mice in a light/dark test. Methods Find. Exp. Clin. Pharmacol. 18, 513-520.

Kenakin, T. (2011). Functional selectivity and biased receptor signaling. J. Pharmacol. Exp. Ther. 336, 296-302. doi: 10.1124/jpet.110.173948

Kubacka, M., Mogilski, S., Bednarski, M., Nowiński, L., Dudek, M., Żmudzka, E., et al. (2016). Antidepressant-like activity of aroxyalkyl derivatives of 2methoxyphenylpiperazine and evidence for the involvement of serotonin receptor subtypes in their mechanism of action. Pharmacol. Biochem. Behav. 141, 28-41. doi: 10.1016/j.pbb.2015.11.013

Lister, R. G. (1987). The use of a plus-maze to measure anxiety in the mouse. Psychopharmacology 92, 180-185. doi: 10.1007/BF0017 7912

Mailman, R. B., and Murthy, V. (2010). Third generation antipsychotic drugs: partial agonism or receptor functional selectivity? Curr. Pharm. Des. 16, $488-501$.

Newman-Tancredi, A. (2011). Biased agonism at serotonin 5-HT1A receptors: preferential postsynaptic activity for improved therapy of CNS disorders. Neuropsychiatry 1, 149-164. doi: 10.2217/npy.11.12

Newman-Tancredi, A., Martel, J. -C., Assié, M. B., Buritova, J., Lauressergues, E., Cosi, C., et al. (2009). Signal transduction and functional selectivity of F15599, a preferential post-synaptic 5-HT1A receptor agonist. Br. J. Pharmacol. 156, 338-353. doi: 10.1111/j.1476-5381.2008.00001.x

Nikiforuk, A. (2015). Targeting the serotonin 5-HT7 receptor in the search for treatments for CNS disorders: rationale and progress to date. CNS Drugs 29, 265-275. doi: 10.1007/s40263-015-0236-0

Parks, C. L., Robinson, P. S., Sibille, E., Shenk, T., and Toth, M. (1998). Increased anxiety of mice lacking the serotonin1A receptor. Proc. Natl. Acad. Sci. U.S.A. 95, 10734-10739. doi: 10.1073/pnas.95.18.10734

Patel, C. B., Noor, N., and Rockman, H. A. (2010). Functional selectivity in adrenergic and angiotensin signaling systems. Mol. Pharmacol. 78, 983-992. doi: $10.1124 / \mathrm{mol} .110 .067066$

Pattij, T. (2002). Autonomic changes associated with enhanced anxiety in 5-HT1A receptor knockout mice. Neuropsychopharmacology 27, 380-390. doi: 10.1016/ S0893-133X(02)00317-2

Pytka, K., Głuch-Lutwin, M., Kotańska, M., Waszkielewicz, A., Kij, A., and Walczak, M. (2017). Single administration of HBK-15-a triple 5-HT1A, 5HT7, and 5-HT3 receptor antagonist-reverses depressive-like behaviors in mouse model of depression induced by corticosterone. Mol. Neurobiol. 68:263. doi: 10.1007/s12035-017-0605-4

Pytka, K., Lustyk, K., Żmudzka, E., Kotańska, M., Siwek, A., Zygmunt, M., et al. (2016a). Chemically homogenous compounds with antagonistic properties at all $\alpha 1$-adrenoceptor Subtypes but not $\beta 1$-adrenoceptor attenuate adrenalineinduced arrhythmia in rats. Front. Pharmacol. 7:229. doi: 10.3389/fphar.2016. 00229

Pytka, K., Żmudzka, E., Lustyk, K., Rapacz, A., Olczyk, A., Gałuszka, A., et al. (2016b). The antidepressant- and anxiolytic-like activities of new xanthone derivative with piperazine moiety in behavioral tests in mice. Indian J. Pharmacol. 48, 286-291. doi: 10.4103/0253-7613. 182872

Pytka, K., Partyka, A., Jastrzêbska-Wiêsek, M., Siwek, A., Głuch-Lutwin, M., Mordyl, B., et al. (2015a). Antidepressant- and anxiolytic-like effects of new dual 5-HT1A and 5-HT7 antagonists in animal models. PLoS One 10:e142499. doi: 10.1371/journal.pone.0142499

Pytka, K., Rapacz, A., Zygmunt, M., Olczyk, A., Waszkielewicz, A. M., Sapa, J., et al. (2015b). Antidepressant-like activity of a new piperazine derivative of xanthone in the forced swim test in mice: the involvement of serotonergic system. Pharmacol. Rep. 67, 160-165. doi: 10.1016/j.pharep.2014. 08.016

Ramboz, S., Oosting, R., Amara, D. A., Kung, H. F., Blier, P., Mendelsohn, M., et al. (1998). Serotonin receptor 1A knockout: an animal model of anxiety-related disorder. Proc. Natl. Acad. Sci. U.S.A. 95, 14476-14481. doi: 10.1073/pnas.95. 24.14476

Sałat, K., Podkowa, A., Kowalczyk, P., Kulig, K., Dziubina, A., Filipek, B., et al. (2015). Anticonvulsant active inhibitor of GABA transporter subtype 1, tiagabine, with activity in mouse models of anxiety, pain and depression. Pharmacol. Rep. 67, 465-472. doi: 10.1016/j.pharep.2014. 11.003

Sibille, E., Pavlides, C., Benke, D., and Toth, M. (2000). Genetic inactivation of the serotonin(1A) receptor in mice results in downregulation of major $\mathrm{GABA}(\mathrm{A})$ receptor alpha subunits, reduction of $\mathrm{GABA}(\mathrm{A})$ receptor binding, and benzodiazepine-resistant anxiety. J. Neurosci. 20, 2758-2765. doi: 10.1523/ JNEUROSCI.20-08-02758.2000

Stroth, N., Niso, M., Colabufo, N. A., Perrone, R., Svenningsson, P., Lacivita, E., et al. (2015). Arylpiperazine agonists of the serotonin 5HT1A receptor preferentially activate cAMP signaling versus recruitment 
of $\hat{\mathrm{I}}^{2}$-arrestin-2. Bioorg. Med. Chem. 23, 4824-4830. doi: 10.1016/j.bmc.2015. 05.042

Tiraboschi, E., Tardito, D., Kasahara, J., Moraschi, S., Pruneri, P., Gennarelli, M., et al. (2004). Selective phosphorylation of nuclear CREB by fluoxetine is linked to activation of CaM kinase IV and MAP kinase cascades. Neuropsychopharmacology 29, 1831-1840. doi: 10.1038/sj.npp.130 0488

Waszkielewicz, A. M., Pytka, K., Rapacz, A., Wełna, E., Jarzyna, M., Satała, G., et al. (2015). Synthesis and evaluation of antidepressant-like activity of some 4substituted 1-(2-methoxyphenyl)piperazine derivatives. Chem. Biol. Drug Des. 85, 326-335. doi: 10.1111/cbdd.12394

Wesołowska, A., Nikiforuk, A., and Stachowicz, K. (2006a). Potential anxiolytic and antidepressant effects of the selective 5-HT7 receptor antagonist SB 269970 after intrahippocampal administration to rats. Eur. J. Pharmacol. 553, 185-190. doi: 10.1016/j.ejphar.2006.09.064

Wesołowska, A., Nikiforuk, A., Stachowicz, K., and Tatarczyńska, E. (2006b). Effect of the selective 5-HT7 receptor antagonist SB 269970 in animal models of anxiety and depression. Neuropharmacology 51, 578-586. doi: 10.1016/j. neuropharm.2006.04.017
Yau, J. L., Noble, J., and Seckl, J. R. (2001). Acute restraint stress increases 5HT7 receptor mRNA expression in the rat hippocampus. Neurosci. Lett. 309, 141-144. doi: 10.1016/S0304-3940(01)02054-7

Żmudzka, E., Sałaciak, K., Sapa, J., and Pytka, K. (2018). Serotonin receptors in depression and anxiety: insights from animal studies. Life Sci. 210, 106-124. doi: 10.1016/j.lfs.2018.08.050

Conflict of Interest Statement: The authors declare that the research was conducted in the absence of any commercial or financial relationships that could be construed as a potential conflict of interest.

Copyright (c) 2018 Pytka, Głuch-Lutwin, Żmudzka, Sałaciak, Siwek, Niemczyk, Walczak, Smolik, Olczyk, Gałuszka, Śmieja, Filipek, Sapa, Kołaczkowski, Pańczyk, Waszkielewicz and Marona. This is an open-access article distributed under the terms of the Creative Commons Attribution License (CC BY). The use, distribution or reproduction in other forums is permitted, provided the original author(s) and the copyright owner(s) are credited and that the original publication in this journal is cited, in accordance with accepted academic practice. No use, distribution or reproduction is permitted which does not comply with these terms. 